\title{
An automated screening technique for the detection of sickle-cell haemoglobin
}

\author{
D. M. CANNING, R. S. CRANE, R. G. HUNTSMAN, AND G. I. YAWSON \\ From the Department of Pathology, Lambeth Hospital (St Thomas' Hospital), Brook Drive, London
}

SYNOPSIS An automated technique is described which is capable of detecting sickle-cell haemoglobi足 and differentiating the sickle-cell trait from sickle-cell anaemia. The method is based upon the Itan $\Theta$ solubility test and utilizes Technicon equipment.

There is an increasing demand for rapid techniques capable of recognizing sickle-cell haemoglobin. The needs of the clinician, anthropologist, and, more recently, the genetic counsellor are already established. However, three other sections of the community may in the future also require testing.

The recently reported deaths of four soldiers with the sickle-cell trait after arduous training at 4060 feet (Jones, Binder, and Donowho, 1970) suggests that all recruits should be screened at the time of enlistment. During a survey of 1000 negro military recruits (Binder and Jones, 1970) 73 were found to have the sickle-cell trait, one had sickle-cell haemoglobin $\mathrm{C}$ disease, and one had sickle-cell thalassaemia.

Passengers with sickle-cell haemoglobin $\mathrm{C}$ disease are particularly liable to sickling crises when travelling by air. In 1961 the Aerospace Medical Association suggested that such people should not fly. Despite this recommendation, sickling crises still occur in passengers on scheduled pressurized flights and these have proved distressing not only to the patient but also to the crew and the other passengers who witness them. If these situations are to be avoided it appears necessary to screen all negro passengers before flight (Green, Huntsman, and Serjeant, 197.1).

Following a fatality during an exchange transfusion of an infant, the donor being a sickle-cell trait carrier (Veiga and Vaithianathan, 1963), it may be argued that all blood donors should be routinely screened for sickle-cell haemoglobin. In practice, sickling-positive blood donors would be likely to have either the sickle-cell trait or sickle-cell haemoglobin $\mathbf{C}$ disease; cases of sickle-cell anaemia and sickle-cell thalassaemia would probably be rejected because of low haemoglobin levels. It might prove administratively more convenient for the blood bank Received for publication 31 August 1971. to screen for the presence of sickle-cell haemoglobin in all donors rather than relying upon a techniciars to reject a blood bottle at the time of cross-matching for neonatal transfusion.

Four techniques, which are not dependent or? electrophoretic separation and which utilize wholes blood, are available for the screening of patients forv sickle-cell haemoglobin.

1 The sickle-cell test (Daland and Castle, 1948) i cheap but false positive and negative results are noĐ uncommon(Schneider, Alperin, and Lehmann, 1967) ڤ

2 Differential elution of normal adult haemoglobiro from sickle-cell haemoglobin in blood films washed in 2.48 M phosphate buffer (Yakulis and Heller, 1964).

3 The Sickledex test (Ortho) is a proprietary prep aration, which detects sickle-cell haemoglobin b居 precipitation. This test is rapid and simple to perform It appears to be reliable (Diggs, Schorr, Ascari, an Reiss, 1968; Loh, 1968; Ballard, Radel, Sakhadeoo and Schorr, 1970; Canning and Huntsman, 1970 but it is expensive and may be prohibitively so if large numbers of examinations are required $₹$ Recently, an automated technique has been described which uses Sickledex reagent. The sickle-cell haemo globin is detected by the impedance of light trans? mission in the turbid sample containing the precipitated haemoglobin (Henry, Nalbandian? Nichols, Wolf, Camp, and Conte, 1970).

4 Non-proprietary tests based upon the Itanow solubility test are also available (Huntsman Barclay, Canning, and Yawson, 1970; French, 1971 Raper, 1971). The automated test described is base upon the manual technique of Huntsman et at (1970). This test detects and distinguishes between the sickle-cell trait and sickle-cell anaemia.

Material and Methods

SAMPLES

Analyses were performed on sequestrenated venous 
blood. To avoid partial clotting, it is essential to ensure that all samples are well mixed at the time of collection.

\section{REAGENTS}

1 Stock buffer to precipitate sickle-cell haemoglobin Potassium dihydrogen orthophosphate ${ }^{1}$. $540 \mathrm{~g}$ Dipotassium hydrogen orthophosphate ${ }^{1} \ldots 952 \mathrm{~g}$ $\begin{array}{lllllll}\text { White saponin } & \ldots & \ldots & \ldots & \ldots & 40 \mathrm{~g}\end{array}$ Distilled water $\quad \ldots \quad \ldots \quad \ldots \quad \ldots \quad$ to 41

Sodium dithionite $(1 \% \mathrm{w} / \mathrm{v})$ is added, before each day's work, to sufficient buffer solution.

\section{Stock total haemoglobin control solution}

$\begin{array}{lllllll}\text { White saponin } & \text {.. } & \text {. } & \text {. } & \text {. } & 40 \mathrm{~g}\end{array}$ Distilled water $\quad . . \quad \ldots \quad \ldots \quad \ldots \quad$ to 41

Sodium dithionite $(1 \% \mathrm{w} / \mathrm{v})$ should again be freshly added each day. Stock solutions 1 and 2 should be refrigerated.

\section{$3 \quad 0.85 \%$ W/V Sodium chloride in distilled water}

\section{Whatman filter paper reels}

Grade 52, width $2 \cdot 5 \mathrm{~cm}$

\section{APPARATUS}

This is illustrated in Figure 1. It consists of a Technicon sampler II with mixer/stirrer attachment

These chemicals must be anhydrous. Unless carefully stoppered a used reagent bottle may contain partially hydrated salts. and 40 samples per hour, one to six samples to buffer wash cam, and the Technicon proportioning pump I which was used for the described work, but a mark II pump would allow for easier arrangement of pump tubes. Helper springs are required under the mark I pump platten.

\section{Technicon continuous filter}

A simple modification (Fig. 2) of the standard filtering unit was prepared in which a $5 \mathrm{~cm} \times 6 \mathrm{~cm}$ Perspex plate, drilled centrally with a $3 \mathrm{~mm}$ hole, was glued on top of the filter block, so that the paper travelled along the $6 \mathrm{~cm}$ length of the Perspex. The leading edge was rounded to allow smooth passage of the paper, which moves at a speed of $5 \mathrm{~cm} / \mathrm{min}$. The mixer assembly was removed, the blood/buffer mixture being debubbled and then allowed to drop from a height of $0.5 \mathrm{~cm}$ to $1 \mathrm{~cm}$ onto the filter paper at a position 1 to $1.5 \mathrm{~cm}$ behind the leading edge of the Perspex support. With this modification, the filter paper became wetted over its entire leading edge immediately before its passage over the Perspex plate. The modification prevents the appearance of numerous air bubbles in the filtrate.

\section{Technicon colorimeters}

Two, fitted with $550 \mathrm{~mm}$ filters and $15 \mathrm{~mm}$ tubular flow cells.

Also required are a two-pen recorder and a $2.5 \mathrm{~K}$ ohm linear potentiometer (variable resistance).

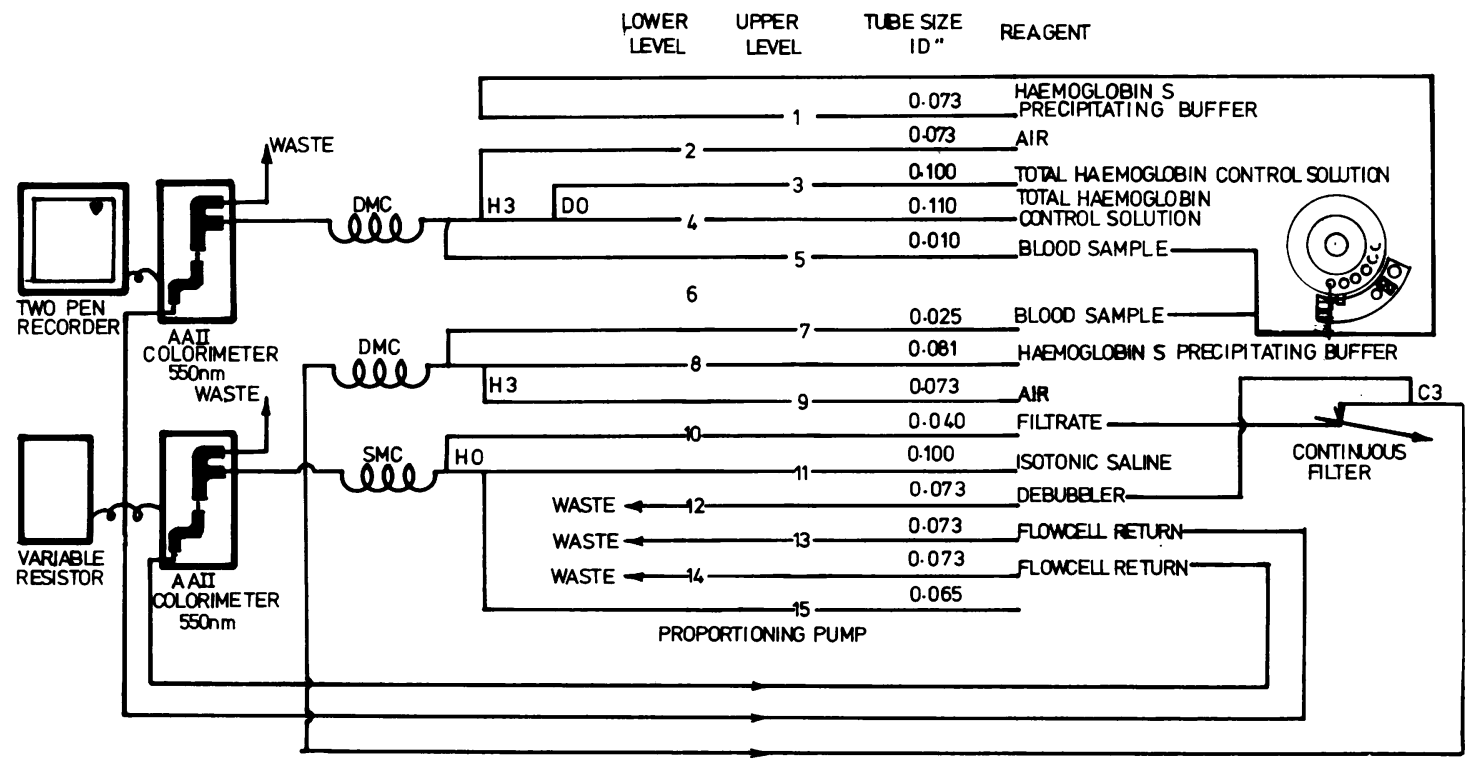

Fig. 1 Flow diagram for the detection of sickle-cell haemoglobin (see apparatus and manifold). 


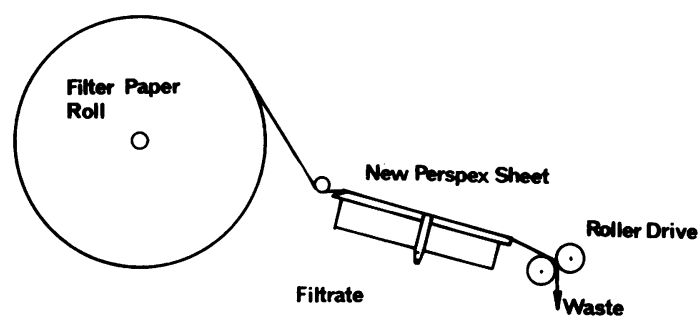

Plan View of Continuous Filter Unit

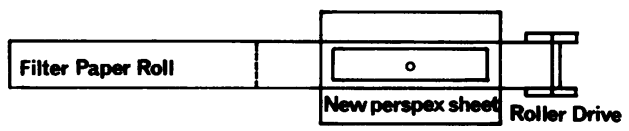

Fig. 2 Adaptation to continuous filter unit (see Apparatus).

\section{MANIFOLD}

The flow diagram is shown in Fig. 1, standard tygon pump tubes being used. The polypropylene sample tubes should be left as short as possible but their lengths can be finely adjusted to superimpose the haemoglobin peaks obtained from each sample. The filtrate line should also be left as short as possible.

After the passage of two samples, the wash characteristics of the system will be established. If, in order to identify the samples, a saline wash cup is periodically inserted, this should be followed by two normal samples before the run is recommenced.

The peak heights should be adjusted by selection of suitably sized pump tubes so that the total haemoglobin peak has equal or slightly greater absorbance than the peak obtained from the filtrate. A fine adjustment can be subsequently made by the insertion of a $2.5 \mathrm{~K} \mathrm{ohm}$ linear potentiometer connected as a variable resistance between the filtrate colorimeter and recorder input (Annan and Fisher, 1971). If the potentiometer is initially set at zero, after the wash characteristics have been established the filtrate peak can, if necessary, be raised by increasing the resistance.

\section{Results}

The following samples have been examined by the automated technique:

\begin{tabular}{lrlr}
\hline Sample & No. & Sample & No. \\
\hline Normal & 131 & Sickle-cell thalassaemia & 1 \\
Sickle-cell trait & 29 & Sickle-cell haemoglobin C disease & 4 \\
Sickle-cell anaemia & 4 & Haemoglobin C trait & 4 \\
Sickle-cell anaemia & & Haemoglobin D trait & 1 \\
with high Hb F & 3 & & \\
\hline
\end{tabular}

All these samples were also examined by the $\frac{0}{\vec{*}}$

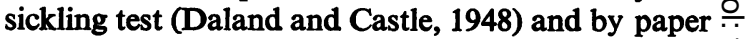
electrophoresis (Cradock-Watson, Fenton, and $\underset{\vec{\rho}}{\vec{\rho}}$ Lehmann, 1959). Any sample in which sickle-cell haemoglobin was detected by either of the above two methods or the described automated technique was in addition subjected to agar gel electrophoresis (Robinson, Robson, Harrison, and Zuelzer, 1957).

In three cases the results of the orthodox sickling test and the new automated test were discrepant. $\overrightarrow{0}$ Subsequent investigation showed that the sickling test had been falsely reported as positive in two cases and negative in one.

Because of the different wash characteristics of the two systems, it is not possible to equate quantitatively of the two peak heights. Figure 3 shows that the total $\rightarrow$ haemoglobin peaks will return almost to zero be- $\omega_{\mathcal{O}}^{\omega}$ tween each peak. An indication, but not an accurate assessment, of the patient's haemoglobin level is $\frac{1}{3}$ possible. In contrast, because of the poorer wash $\vec{\longrightarrow}$ characteristics of the non-sickle haemoglobin $\frac{D}{0}$ (filtrate) system, this peak height is to some extent influenced by the amount of the non-sickle haemo- 0 globin in the preceding specimen. For example, one $N$ would expect the filtrate peak height of the specimen following a sample of sickle-cell anaemia to be somewhat reduced (peaks 12 and 13 in Fig. 3). For a similar reason, a preceding high filtrate peak will tend to elevate the following filtrate peak (peaks 15 and 16 in Fig. 3). This phenomenon could be reduced by introducing a buffer-filled cup between each sample. However, simple observation of a 40sample an hour run should prove adequate to differentiate normal samples from the sickle-cell trait and sickle-cell anaemia.

\section{Discussion}

Apart from the capital expenditure ( $£ 3$ 850) the running costs are negligible (approximately 200 tests 욱 per $£ 1$ including disposable AutoAnalyzer cups).

The automated test suffers from the same disadvantages as the manual technique upon which it is based. It fails to distinguish between sickle-cell trait $\sigma$ and sickle-cell haemoglobin $\mathrm{C}$ disease (peaks 6 and $\mathrm{N}$ 8 , Fig. 3) and it also fails to distinguish the unusual $\underset{\omega}{N}$ benign cases of sickle-cell anaemia with high foetal $\sigma$ haemoglobin from the sickle-cell trait. All samples

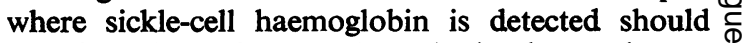
therefore be subsequently submitted to electro- $\stackrel{0}{?}$ phoresis.

Whilst the test appears capable of detecting and distinguishing between sickle-cell anaemia and the sickle-cell trait in samples adjusted to as low as $5 \mathrm{~g} \% \mathrm{Hb}$ level (peaks 18 and 20, Fig. 3) the distinction becomes progressively more difficult as the 


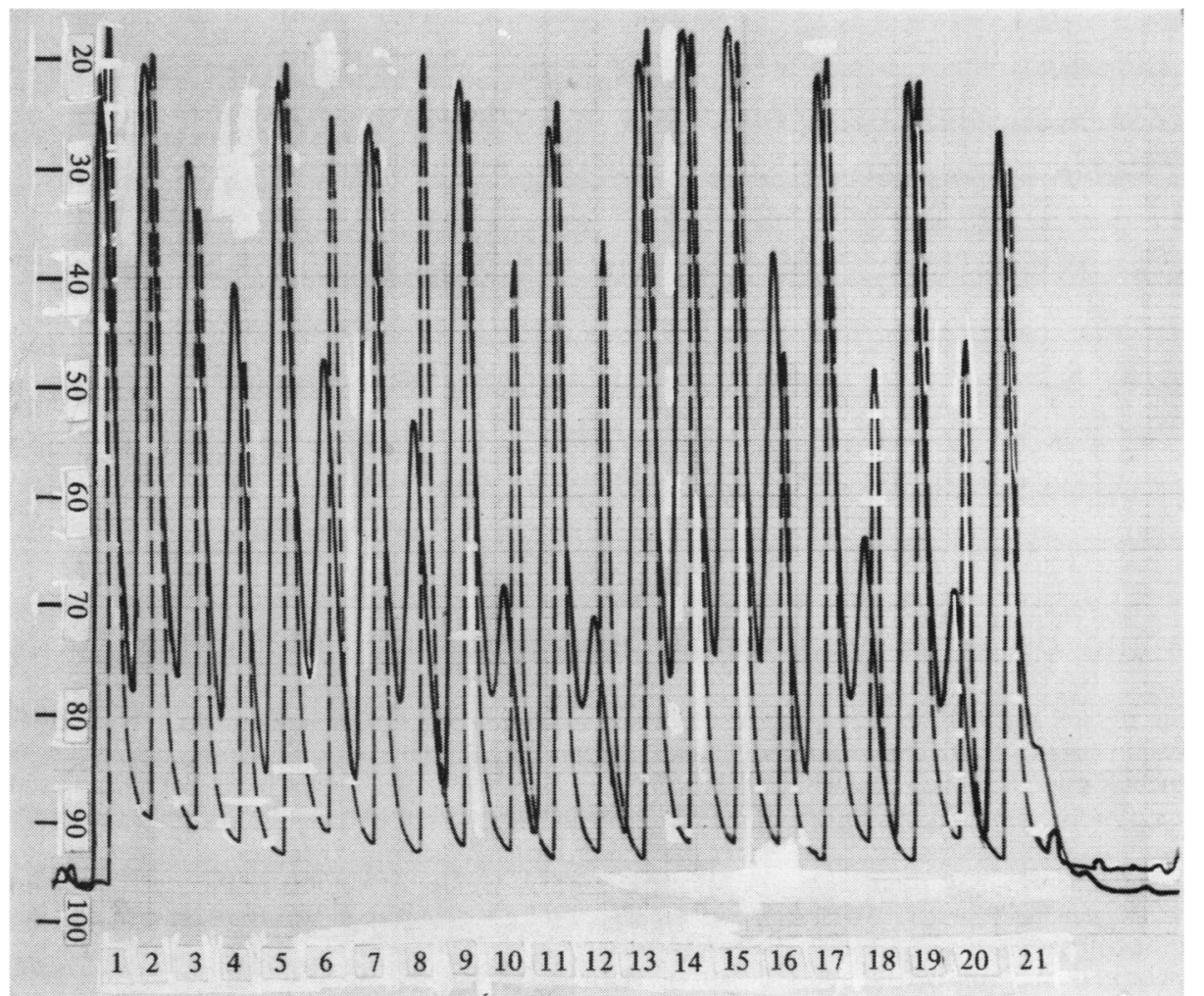

Fig. 3 A tracing of the patterns obtained in the analyzer on a number of selected samples.

Tracing of the filtrate after precipitation of the sickle-cell haemoglobin.

- . - . . . . - Tracing of the total reduced haemoglobin.

1 normal $(15 \mathrm{~g} / 100 \mathrm{ml}), 2$ normal $(15 \mathrm{~g} / 100 \mathrm{ml}), 3$ normal $(10 \mathrm{~g} / 100 \mathrm{ml}), 4$ normal $(5 \mathrm{~g} / 100 \mathrm{ml}), 5$ normal $(15 \mathrm{~g} / 100 \mathrm{ml}$ ), sickle-cell trait, 7 normal $(15 \mathrm{~g} / 100 \mathrm{ml}), 8$ sickle-cell haemoglobin C disease, 9 normal $(15 \mathrm{~g} / 100 \mathrm{ml})$, 10 sickle-cell thalassaemia, 11 normal $(15 \mathrm{~g} / 100 \mathrm{ml}), 12$ sickle-cell anaemia, 13 normal $(15 \mathrm{~g} / 100 \mathrm{ml}), 14$ normal $(15 \mathrm{~g} / 100 \mathrm{ml}), 15 \mathrm{normal}(15 \mathrm{~g} / 100 \mathrm{ml}), 16$ normal $(5 \mathrm{~g} / 100 \mathrm{ml}), 17$ normal $(15 \mathrm{~g} / 100 \mathrm{ml}), 18$ sickle-cell trait $(5 \mathrm{~g} / 100 \mathrm{ml}), 19$ normal $(15 \mathrm{~g} / 100 \mathrm{ml}), 20$ sickle-cell anaemia $(5 \mathrm{~g} / 100 \mathrm{ml}), 21$ normal $(15 \mathrm{~g} / 100 \mathrm{ml})$.

level of haemoglobin falls. In order to avoid false negative results it appears desirable that all anaemic samples (below $10 \mathrm{~g} \%$ ) should be retested after the haemoglobin level has been recorded. The second test is carried out with the packed cell volume adjusted to approximately $50 \%$. This is achieved by pipetting off the excess plasma in the sedimented AutoAnalyzer cup. A clear distinction between the sickle-cell trait and sickle-cell anaemia will then be possible.

The authors are indebted to the haematology staff of the Greenwich District Hospital, the London Hospital, and St Stephen's Hospital, Chelsea, for blood samples.

\section{References}

Aerospace Medical Association (1961). Committee on Medical $3 *$
Annan, W., and Fisher, G. W. (1971). A range expander unit for Auto-Analyzer recorders. Med. Lab. Technol., 28, 308-309.

Ballard, M. S., Radel, E., Sakhadeo, S., and Schorr, J. B. (1970). A new diagnostic test for hemoglobin S. J. Pediat., 76, 117-119.

Binder, R. A., and Jones, S. R. (1970). Prevalence and awareness of sickle-cell hemoglobin in a military population. J. Amer. med. Ass., 214, 909-911.

Canning, D. M., and Huntsman, R. G. (1970). Assessment of Sickle dex as an alternative to the sickling test. J. clin. Path., 23, 736737.

Cradock-Watson, J. E., Fenton, J. C. B., and Lehmann, H. (1959). TRIS buffer for the demonstration of haemoglobin $A_{2}$ by paper electrophoresis. J. clin. Path., 12, 372-373.

Daland, G. A., and Castle, W. B. (1948). A simple and rapid method for demonstrating sickling of the red blood cells. J. Lab. clin. Med., 33, 1082-1088.

Diggs, L. W., Schorr, J. B., Ascari, W. Q., and Reiss, A. (1968). A new diagnostic test for hemoglobin S. In Proc. Amer. Soc. clin. Path. and Coll. Amer. Path., 22nd Joint Annual Meeting.

French, E. A. (1971). An alternative to the sickling test. (Letter.) $J$. clin. Path., 24, 91.

Green, R. L., Huntsman, R. G., and Serjeant, G. R. (1971). The sickle-cell and altitude. Brit. med. J., 4, 593-595

Henry, R. L., Nalbandian, R. M., Nichols, B. M., Wolf, P. L., Camp, F. R., and Conte, N. F. (1970). An automated specific method 
for the detection of $S$. hemoglobin advances in automated analysis. (Technicon International Congress, Nov. 1970.)

Huntsman, R. G., Barclay, G. P. T., Canning, D. M., and Yawson, G. I. (1970). A rapid whole blood solubility test to differentiate the sickle-cell trait from sickle-cell anaemia. J. clin. Path., 23, 781-783.

Jones, S. R., Binder, R. A., and Donowho, E. M., Jr. (1970). Sudden death in sickle-cell trait. New Engl. J. Med., 282, 323325.

Loh, W. P. (1968). A new solubility test for rapid detection of hemoglobin S. J. Indiana med. Ass., 61, 1651-1652.

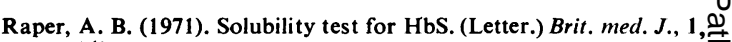

Robinson, A. R., Robson, M., Harrison, A. P., and Zuelzer, w. w. $\frac{\mathrm{\sigma}}{\mathrm{T}}$ (1957). A new technique for differentiation of hemoglobin. $J . \Rightarrow$ Lab. clin. Med., 50, 745-752.

Schneider, R. G., Alperin, J. B., and Lehmann, H. (1967). Sickling tests. J. Amer. med. Ass., 202, 419-421.

Veiga, S., and Vaithianathan, T. (1963). Massive intravascularo sickling after exchange transfusion with sickle cell trait blood. $\overline{\bar{c}}$. Transfusion, 3, 387-391.

Yakulis, V. J., and Heller, P. (1964). An elution test for the visualization of hemoglobin $\mathrm{S}$ in blood smears. Blood, 24, 198-201.

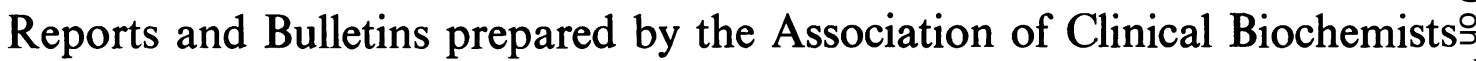

The following reports and bulletins are published by the Association of Clinical Biochemists. They may be obtainedo from The Administrative Office, Association of Clinical Biochemists, 7 Warwick Court, Holborn, London, WC1R 5DP. The prices include postage, but air mail will be charged extra. Overseas readers should remit by British Postal or Moneye Order. If this is not possible the equivalent of $50 \mathrm{p}$ is the minimum amount that can be accepted.

\section{SCIENTIFIC REPORTS}

3 Automatic Dispensing Pipettes. An assessment of 35 commercial instruments 1967 P. M. G. BROUGHTON, A. H. GOWENLOCK, G. M. WIDDOWSON, and K. A. AHLQUIST $85 p(\$ 2)$

4 An Evaluation of five Commercial Flame Photometers suitable for the Simultaneous Determination of Sodium and Potassium March 1970 P. M. G. BROUGHTON and J. B. DAWSON $85 \mathrm{p}(\$ 2)$

\section{SCIENTIFIC REVIEWS}

1 The Assessment of Thyroid Function March 1971 F. V. FLYNN and J. R. HOBBS $62 \frac{1}{2} p(\$ 1.50)$

2 Renal Function Tests Suitable for Clinical Practice January 1972 F. L. MITCHELL, N. VEALL, and R. W. E. WATTS $62 \frac{1}{2} \mathrm{p}(\$ 1.50)$

\section{TECHNICAL BULLETINS}

9 Determination of Urea by AutoAnalyzer November 1966 RUTH M. HASLAM $42 \frac{1}{2} p(\$ 1)$

11 Determination of Serum Albumin by AutoAnalyzer using Bromocresol Green October 1967 B. E. NORTHAM

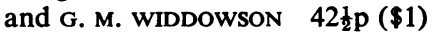

13 An Assessment of the Technicon Type II Sampler Unit March 1968 B. C. GRAY and G. K. MCGOWAN $42 \frac{1}{2} p(\$ 1)$

14 Atomic Absorption Spectroscopy. An outline of its principles and a guide to the selection of instruments May 1968 J. B. DAWSON and P. M. G. BROUGHTON $42 \frac{1}{2} p(\$ 1)$
15 A Guide to Automatic Pipettes (2nd edition) June 1968 P. M. G. BROUGHTON $42 \frac{1}{2} p(\$ 1)$

16 A Guide to Automation in Clinical Chemistry May气

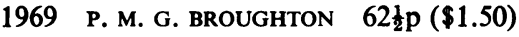

17 Flame Photometers (2nd edition) 1969 P. WILDING $\overrightarrow{\bar{O}}$ $62 \frac{1}{2} \mathrm{p}(\$ 1.50)$

18 Control Solutions for Clinical Biochemistry (4tho edition) March 1970 P. M. G. BROUGHTON $62 \frac{1}{2} \mathrm{p}$ (\$1.50)

19 Spectrophotometers. A comparative list of low-priced3. instruments readily available in Britain May 1970 c. E. WILDE and P. SEWELL $62 \frac{1}{2} \mathrm{p}(\$ 1.50)$

20 Quantities and Units in Clinical Biochemistry June을

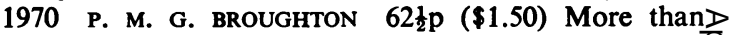
30 copies in units of 10 at $20 \mathrm{p}$

21 Filter Fluorimeters: A comparative list of 18 instruments September 1970 H. BRAUNSBERG and S. S.N BROWN 62 $\frac{1}{2} p(\$ 1.50)$

22 Bilirubin standards and the Determination of Bilirubin by Manual and Technicon AutoAnalyzer Methodso January 1971 BARBARA BILLING, RUTH HASLAM and N. WALD $62 \frac{1}{2} \mathrm{p}(\$ 1.50)$

23 Interchangeable Cells for Spectrophotometers and $\frac{T}{O}$ Fluorimeters September 1971 E. S. BROWN and A. H. GOWENLOCK $62 \frac{1}{2} \mathrm{p}(\$ 1.50)$

24 Simple Tests to Detect Poisons March 1972 B. w. MEADE et al. $\quad 62 \frac{1}{2}(\$ 1.50)$ 